\title{
The relationship between narrative construction and identity in History \\ Education: implications for teaching and learning
}

\section{A relação entre a construção narrativa e a identidade na Educação Histórica: implicações para o ensino e para o aprendizado}

\author{
Terrie Epstein ${ }^{1}$
}

\begin{abstract}
The purpose of the research is less about producing little historians and more about taking into account students' cultures or identities in the teaching and learning of historical narratives. In my work, I have examined the national historical narratives that children and adolescents in the United States have constructed in order to assess the effects of young people's racial/ethnic identities on their understandings of the past. I have found that young people's racial identities had a significant impact on their interpretations of the U. S. history and that their teachers' instruction had some but not much impact on their views. Researchers within and beyond the U. S. have found similar results, attesting to the significance of "identity" (a person's sense of self and the communities s/he affiliates with, including nationality, gender, ethnicity, religious orientation, etc.) in the construction and/or critique of historical narratives. In the following pages, I review and synthesize the studies that I and others have conducted on the effects of identity on history teaching and learning, and conclude with a discussion of the implications for teaching and learning history in diverse democratic societies.
\end{abstract}

Keywords: identity; historical narratives; learning history.

DOI: $10.1590 / 0104-4060.46024$

1 Hunter College of the City University of New York. New York, New York, United States. 695 Park Ave, 10065.E-mail: tepstein@hunter.cuny.edu 


\section{RESUMO}

O objetivo da pesquisa é menos sobre gerar pequenos historiadores e mais sobre levar em conta as culturas ou identidades dos alunos no ensino e aprendizado de narrativas históricas. No meu trabalho, eu examinei as narrativas históricas nacionais que as crianças e os adolescentes nos Estados Unidos elaboraram, a fim de avaliar os efeitos das identidades raciais/étnicas dos jovens nos entendimentos deles do passado. Descobri que as identidades raciais dos jovens tiveram um impacto significativo nas interpretações deles da história dos Estados Unidos e que a formação dos professores deles teve algum impacto, mas não muito impacto sobre as visões deles. Os pesquisadores nos EUA e para além dos EUA encontraram resultados similares, confirmando o significado de "identidade" (o sentido do eu da pessoa e as comunidades às quais ela/ele se filia, incluindo nacionalidade, gênero, etnicidade, orientação religiosa, etc.) na elaboração e/ou na análise crítica das narrativas históricas. Nas páginas seguintes, revejo e sintetizo os estudos que eu e outros realizamos sobre os efeitos de identidade no ensino e na aprendizagem de história, e concluímos com uma discussão sobre as implicações do ensino e da aprendizagem de história em várias sociedades democráticas.

Palavras-chave: identidade; narrativas históricas; aprendizado de história.

For the past 50 years, researchers in the Americas and Western Europe have conducted studies on young people historical thinking. Framing their work within theories of cognition and the epistemology of history, scholars have investigated how children and adolescents make meaning of historical concepts such as significance, empathy, cause and effect, evidence, etc., and use those concepts to construct and critique historical narratives (BOOTH, 1994; SHEMILT, 1980; STEARNS; SEIXAS; WINEBURG, 2000). Influenced originally by Piagetian stages of cognitive development and more recently by expert-novice studies of academic disciplines, cognitive researchers have focused on "learning from the inside out"; i.e., how individual students use history's concepts and procedures to evaluate and create historical narratives. For cognitively oriented history education researchers, the aim is that students learn to think and write as historians do (or as close to that as possible), and to use the skills of historical analysis to become "reasoned" citizens in democratic societies.

Since the turn of the twenty-first century, researchers have turned to another set of theories to examine student historical learning. Sociocultural theories or approaches to history education focus on the political, social and cultural contexts in which all historical narratives are embedded. Unlike cognitive approaches that focus on how individuals use reason and evidence to make historical claims, 
sociocultural approaches approach learning from "the outside in"; i.e. historical narratives and other forms are cultural tools that circulate within communities that people internalize to more or less degrees to make meaning of the past. The purpose of sociocultural research is not so much tied to understanding how individual students employ historical concepts and methods to arrive at reasoned historical narratives. Rather, it is to unravel the political and cultural dimensions of historical thinking, how people in distinct and overlapping communities tell some but not other stories about the past, based in part on their affiliations with various communities. The purpose of the research is less about producing little historians and more about taking into account students' cultures or identities in the teaching and learning of historical narratives.

In my work, I have examined the national historical narratives that children and adolescents in the United States have constructed in order to assess the effects of young people's racial/ethnic identities on their understandings of the past. I have found that young people's racial identities had a significant impact on their interpretations of the U. S. history and that their teachers' instruction had some but not much impact on their views. Researchers within and beyond the U. S. have found similar results, attesting to the significance of "identity" (a person's sense of self and the communities s/he affiliates with, including nationality, gender, ethnicity, religious orientation, etc.) in the construction and/or critique of historical narratives. In the following pages, I review and synthesize the studies that I and others have conducted on the effects of identity on history teaching and learning, and conclude with a discussion of the implications for teaching and learning history in diverse democratic societies.

\section{The Studies}

\section{Setting and participants}

In 2009, I published a book entitled, Interpreting national history: Race, identity and pedagogy in classrooms and communities (Routledge Press). The book included analyses of the historical narratives of children, adolescents, teachers and parents in one working-class community in the state of Michigan. The community had about equal numbers of African American ("black") and European American ("white") families. I collected data in: two fifth-grade (10 years old); two eighth-grade (13 years old) and two eleventh-grade (16 year olds) U. S. history classrooms. All of the classroom teachers were white and in each classroom, I collected data on five white and five black students at the 
beginning and end of the school year. By comparing students' responses at the beginning and end of the year, I assessed the effects of instruction on students' responses. In addition, by comparing black and white students' responses, I evaluated the effects of their racial identities on their views of the U. S. history.

\section{Nation narration task/data collection}

To elicit students' views of national history, they participated in a "nation narration" task at the beginning and end of the year. Students received about 40 picture cards of important historical actors and events and were asked to select, place in chronological order, and explain the 20 most important $\left(5^{\text {th }}\right.$ graders were given fewer cards). The cards included traditional historical actors and events - George Washington, the American Revolution - as well as those related to African American history. I did this so that students could create completely traditional textbook-type historical narratives, narratives that primarily featured African American actors or events, or anything in between. I also asked each of the teachers to complete the task, as well as 12 black and 12 white parents of students in the study. Finally, during the 6 years I worked on the study, I attended many community events that featured black and/or white adolescents as "civic actors", i.e., events where students presented essays on citizenship, student assemblies honoring Black History Month, etc. From the data, I gained a broad understanding of the types of narratives about the U. S. history that children, adolescents and adults in the community constructed in school and out-of-school contexts.

\section{Findings}

\section{Significance of identity}

Two major findings emerged from the six-year investigation. First and foremost, I found children's, adolescents' and adults' racial identities had a significant impact on their constructions of the U. S. history. White children, adolescents and adults (teachers and parents) constructed narratives in which white people were historical actors who contributed to national development and black people were historical victims, except during the Civil Rights Movement. In discussing race relations, white students and adults rarely referred to the violence associated with enslavement and other historic forms of racial oppression; instead, they referred to "black inequality", but not to white-on-black 
violence. In addition, white students and adults had a "progressively inclusive" concept of individual rights: even though the U. S. began with only white men of property having rights, the nation over time increased the franchise so that now all people have equal rights. Finally, white students rated textbooks, teachers and library books as the most credible places to get historical information; they tended to trust the historical narratives they learned in school and the family stories they heard about relatives and ancestors fit well within traditional view of the U. S. history taught in schools and in mainstream society.

Black children, adolescents and adults constructed different concepts of the roles of historical actors, race relations and the meaning of rights in national history. Black students and adults also saw white actors as nation builders, but also described them as "oppressors" or "keeping down" blacks and other people of color. Black students and adults were much more likely than whites to discuss black historical actors as actors as well as victims. Like whites, they described race relations in terms of inequality, but unlike whites, they also referred to violence: white people "beat" blacks during enslavement and up until the present day. And unlike whites who explained the historical development of rights as "progressively inclusive", black students and adults conceptualized rights as "perennially exclusive." That is, when black students or adults talked about the history of individual rights, they discussed exclusionary practices, such as "even though the Emancipation Proclamation ended slavery, whites still found ways to keep black people down." Black students rated family members, black teachers and documentaries by or about black people as the most credible sources of information on the past; they considered school textbooks and most teachers as not providing the "whole story." Finally, because schools and the mainstream media marginalized black history, black children and their parents oftentimes participated in civic-oriented events sponsored by the black community to present or learn about black history and contemporary life.

\section{Teacher effects on explanations vs. interpretations}

The other major finding of my work referred to the effects of the six teachers' instruction on students' narratives. None of the teachers were "exemplary" or reform minded; most taught history traditionally, relying on lecturing, recitation, worksheets and on a few occasions, more creative activities. Nevertheless, by the end of the school year, many black and white students appropriated their teacher's explanations about historical actors or events, but did not change the "schematic templates" (WElertsch, 2002) or overall interpretative frameworks that situated historical actors or events into a narrative. For example, both black and white students included in their end-of-year narratives content they had 
learned from the teacher and their end-of-year narratives were richer or more "informative" than the narratives they constructed at the beginning of the year.

At the same time, both black and white students appropriated information that fit into their pre-existing interpretive frameworks and ignored that which challenged their views. So at the end of the year, white students incorporated into their narratives their teachers' content about the Civil Rights Movement as a period when whites and blacks together protested peacefully for civil rights, but they did not mention examples of racial violence, which teachers also taught. Black students in the same class reflected the teacher's instruction about violence, but rarely mentioned white people's participation in the Civil Rights Movement. Each group of students at the end of the year assimilated into their historical narratives instructional content that fit into their pre-existing frameworks: white students included content related to greater equality and excluded content on white-on-black violence; black students, on the other hand, incorporated historical content that reinforced rather than revised existing themes about racial violence and inequality but rarely mentioned white cooperation during the period.

\section{Follow up study}

In a follow up study (2011), I examined the effects of one New York City history teacher's instruction on African American and Latino low-income youth. The teacher taught a "culturally relevant" history class: she integrated the histories of African Americans and Latinos into a traditional U. S. history class in ways that treated people from oppressed groups as historical actors (as well as victims) and related the variety of resistance strategies that historically marginalized groups have used to struggle for greater freedom or equality. She also gave several lessons about poor whites, many of which shared the interests of other marginalized populations, as well as "white allies", i.e., whites throughout history that worked for greater equality for marginalized groups. She also used a variety of creative activities to engage students in "critical literacy"; i.e., the ability to read and write texts and other forms from critical perspectives, asking about how the author's point of view affects her writing of the past, etc.

What I found is that the teacher's instruction had mixed results. At the end of the year, students viewed African Americans, Latinos and other marginalized groups as more agentic and less victimized than they had at the beginning of the year. Students also discussed the variety of strategies marginalized groups used to fight for equality. But the students still tended to view whites as a monolithic 
group that oppressed others. On occasion, the students made a distinction between white men and women, with women having had to struggle for equality, similar in some ways to the struggles of people of color. But overall at the end of the year, the students primarily saw white people historically as a monolithic privileged group; they did not internalize the teacher's instruction about the heterogeneity of white people's historical experiences.

\section{Additional Studies on History and Identity}

Several researchers across the globe have examined how young people's identities interact with and shape their understandings of the nation's past. In one study, Barton and McCully (2010) investigated how high school students in Northern Ireland conceptualized national history. Northern Ireland is considered a "post-conflict" society, where armed struggle between Catholics and Protestants officially only ended in 1998. History taught in Irish schools avoids sectarian perspectives; instead of teaching a "Catholic" or "Protestant" oriented history connected to recent conflict, the schools teach an evidence-based analytic history that avoids connections to past or present sectarian positions. Contrary to previous studies, including my own, the authors found that adolescents were aware that "community based" historical narratives (i.e., those emanating from the Catholic or Protestant community) were less "balanced" and used for political purposes of the community, and students appreciated the more balanced approach of school history, especially in learning about the historical narratives of the "other" community. At the same time, as the authors wrote,

even as they [students] sought expanded historical viewpoints, however, they were unwilling to abandon the political commitments of their communities, and they sought greater contemporary relevance for history than they were likely to encounter in school. These students thus were not simply appropriating or resisting particular historical narratives; they were engaged in a more complex process that involved developing internally persuasive discourse as they drew from multiple historical discourses in an attempt to form their own point of view on the region's troubled past. (BARTON; MCCULLY, 2010, p. 142). 
Given the complexity of student thought, the authors recommended that students in Northern Ireland and elsewhere might benefit from a curriculum that "attends more directly to their active construction of historical meaning and supports them in constructing critical perspectives on the contemporary relevance of the past" (BARTON; MCCULLY, 2010, p. 142).

In 2010, Carla Peck, a Canadian researcher, designed a study where she asked high school students to construct a narrative of Canada's history and to comment on how their ethnic identities influenced their narratives. Peck found that not only did young people's ethnic identities influence the narrative templates they employed as well as the criteria they used to select events. She also found that many students articulated "complicated notions of their identities, with some perceiving that particular 'sides' of their identity were at play, or in use, during the research task" (PECK, 2010, p. 574). For example, Aboriginal students constructed narratives underwritten by the theme of the loss suffered by Aboriginals historically or as the loss of identity among Aboriginal people. Two native white Canadian students constructed narratives based on traditional European settlement and expansion, while also including events related to the nation's contemporary multiculturalism. Even though the "Canadian" youth constructed somewhat different narratives using the same historical actors and events, each understood to a great degree how his or her ethnicity shaped his or her interpretation of the past.

More recently, two studies have demonstrated how the effects of young people's ethnic identities on their views of history can lead to more or less disciplinary understandings. Bermudez (2012) analyzed online discussions of U.S. high school students discussing a 1992 police beating case of an African American man that prompted massive protests. She found that student comments demonstrated one of two larger socio-historical narratives: one that racism is a contemporary reality that has its roots in the past and another discourse that racism is a "self-perpetuating fiction, resulting from 'blacks' and other 'minorities') resentment against white people" (BERMUDEZ, 2012, p. 208). In presenting aspects of one or the other discourse, students argued about when or whether it was appropriate to connect the history of race relations to more contemporary accounts, and their arguments often were based on their sense of their own or others' ethnic identities, as well as mired in emotion and values. She demonstrated how historical thinking, or in this case argument, is influenced by identity as well as by positionality, or who is talking/writing back to whom and for what purpose. In other words, "there is a social dynamic at play in which participants negotiate narratives, meanings and identities [...] learning and understanding history is situated in social and interpersonal relationships that motivate thinking, and bear its consequences" (BERMUDEZ, 2012, p. 216-217). 
One final example. In an Israeli study, Goldberg (2013) asked Jewish Israelis of Ashkenazi (European) and Mizrahi (Middle Eastern) descent to discuss a controversial historical incident that occurred between the two groups. Not surprisingly, he found that students interpreted the evidence related to and expressed empathy for the group with which they affiliated. Nevertheless, he also found that social identities and intergroup interactions motivated students to elaborate on their arguments and did so by using disciplinary practices of historical inquiry. In short, Goldberg demonstrated how discussions between ethnically distinct Jewish groups led students to invoke more, rather than less, historical thinking.

The work on the effects of young people's social identities on their historical understandings has entered more sophisticated spaces. Starting with studies that have demonstrated differences in young people's understandings based on their distinct cultural identities, more recent studies have shown how students mobilize their identities, as well as more or less sophisticated historical understandings, to argue for or against particular historical interpretations. The research on social identity and narrative constructions of history will continue to inform our understanding of young people's historical understandings, and hopefully incorporate ways to accept and respect the effects of young people's identities on their historical thinking, as well as develop their understandings with the disciplinary tools of historical inquiry.

\section{REFERENCES}

BARTON, K. C.; MCCULLY, A. You can form your own point of view: Internally persuasive dialogue in Northern Ireland students' encounters with history. Teachers College Record, v. 112, n. 1, p. 142-181, 2010.

BERMUDEZ, A. The discursive negotiation of cultural narratives and social identities in learning history. In: CARRETERO, M.; ANENSIO, M.; RODRIGUEZ-MONEO, M. (Eds.). History education and the construction of identities. Charlotte, NC: Information Age Publishing, 2012. p. 203-220.

BOOTH, M. (1994). Cognition in history: A British perspective. Educational Psychologist, v. 29, n. 2, p. 61-69, 2012.

EPSTEIN, T. Interpreting national history: Race, identity and pedagogy in classrooms and communities. New York: Routledge Press, 2009. 
EPSTEIN, T.; MAYORGA, E.; NELSON, J. Teaching about race in an urban history class: The effects of culturally responsive teaching. Journal of Social Studies Research, v. 28, n. 1, p. 1-28, 2011.

GOLDBERG, T. It's in my veins: Identity and disciplinary practice in students' discussions of a historical issue. Theory and Research in Social Education, v. 41, n. 1, p. 33-64, 2013.

PECK, C. L. It's not like [I'm] Chinese and Canadian. I am in between: Ethnicity and students' conceptions of historical significance. Theory and Research in Social Education, v. 38, n. 4, p. 574-617, 2010.

SHEMILT, D. History 13-16 Evaluation Study. London: Holmes McDougal, 1980.

STEARNS, P.; SEIXAS, P.; WINEBURG, S. Knowing, teaching and learning history: national and international perspectives. New York: NYU Press, 2000.

WERTSCH, J. Voices of collective remembering. Cambridge: Cambridge University Press, 2002.

Submitted: March 23, 2016. Approved: March 27, 2016. 